\title{
DRUG TESTING IN THE TRUCKING INDUSTRY: THE EFFECT ON HIGHWAY SAFETY*
}

\author{
MIREILLE JACOBSON \\ University of California, Irvine
}

\begin{abstract}
This paper uses a set of "natural experiments," created by the passage of a U.S. Department of Transportation drug-testing mandate and 13 state testing laws, to examine the effects of testing truckers for illicit substances on highway safety. Since truckers do not bear the full costs of their driving and employers cannot contract on all aspects of their behavior, drug testing may be one means for companies to either screen or monitor employees and lower expected accident costs. Indeed, I find that testing led to a 9-10 percent reduction in truck accident fatalities. The social benefits of mandated testing appear to outweigh the costs of the program. However, the similarity between the effect of mandating testing and simply clarifying state law suggests that extending the right to perform drug tests may have been as effective at lower cost.
\end{abstract}

I

$\mathrm{N}$ the 1980s, in an effort to step up its "War on Drugs," the federal government began a widespread campaign to promote workplace drug testing. Trucking, and the transportation industry more generally, became the natural target of testing advocates. Although trucking companies implemented some safety and productivity measures on their own, such as the adoption of onboard computerized monitoring devices, drug testing was mandated by the federal government. Prior to state legislative and federal regulatory activity in the late 1980s, there was little testing in the industry. Thus, a priori, it is unclear if the benefits of testing outweigh the costs.

I assess this issue by using a panel of states to look at the effects of drug testing on truck-involved highway fatalities. I exploit a set of "natural experiments" created by the passage of drug-testing laws by 13 states between 1987 and 1989 as well as the 1990 implementation deadline for a U.S. Department of Transportation (DOT) testing mandate to examine whether

* I am extremely grateful to Claudia Goldin and Larry Katz for their suggestions throughout the research process. I also thank William N. Evans, Thomas N. Hubbard, Srikanth Kadiyala, Robert Kaestner, Jeffrey Miron, Sam Peltzman, Charles Rombro, Peter F. Swan, an anonymous referee for the Journal of Law and Economics, and the participants of Harvard University's labor lunch series for their helpful comments. Financial assistance is gratefully acknowledged from the National Science Foundation's Graduate Research Fellowship Program and the Lindesmith Center's Fellowship in Drug Policy Studies.

[Journal of Law and Economics, vol. XLVI (April 2003)]

(C) 2003 by The University of Chicago. All rights reserved. 0022-2186/2003/4601-0006 $\$ 01.50$ 
drug screening is an effective policy instrument. I find that laws allowing drug testing reduced truck accident fatalities between 9 and 10 percent. These findings are robust to the inclusion of a broad set of traffic safety covariates and to several specification checks.

On the basis of standard value-of-life estimates, the benefits of testing in the trucking industry, an industry in which one worker's poor judgment can have multiplicative negative safety consequences, seem to outweigh the costs of the federally mandated testing program. Despite the fairly large estimated benefits, few firms were testing prior to the federal mandate, apparently because of uncertainty over the legal ramifications of drug testing. Indeed, the similarity between the effect of mandated testing on truck accident fatalities and the state laws clarifying the legal boundaries of testing suggests that extending the right to perform drug tests on employees in safety-sensitive positions may have been equally effective and would have come at a lower cost. I provide some suggestive evidence of this following the presentation of the cost-benefit analysis.

While the present study establishes the net benefits of drug testing workers in safety-sensitive positions, it leaves open the question of the value of testing employees who, unlike truckers, do not pose significant safety risks. Why, for example, did nearly half of Fortune 500 companies have some type of drug-testing program by 1993 ? $^{1}$ Do these firms view testing as a cost-effective measure of worker productivity or an easy way to signal compliance with federal drug-free workplace regulations and incentive programs? Although beyond the scope of this paper, drug testing in the broader workforce is an issue that continues to generate considerable debate among civil libertarians on the one hand and advocates of zero-tolerance drug policies on the other.

This paper begins with an overview of drug testing. Section II provides a brief summary of related research, and Section III an informal framework for determining how testing may have reduced truck accident fatalities. Section IV uses the time-series variation in testing created by the mandate to look at the effect of testing on aggregate trends in truck accidents. Section $\mathrm{V}$, the core of the paper, exploits the time-series and cross-sectional variation in the likelihood that truckers are screened for drugs, from the combination of state laws and the DOT mandate, to show that testing significantly reduced truck accident fatalities. Section VI presents concluding remarks.

\section{Overview of Drug Testing}

The mid-1980s mark a turning point in employee drug testing. In 1986, President Ronald Reagan issued Executive Order 12564, the Drug Free Workplace Program (DFWP), which directed all government agencies to make

${ }^{1}$ See Tyler D. Hartwell, Prevalence of Drug Testing in the Workplace, 118 Monthly Lab. Rev. 35 (1996). 
TABLE 1

History of Federal Laws on Drug Testing in the Workplace

\begin{tabular}{|c|c|c|}
\hline Date & Legislation/Regulation & Impact/Requirements \\
\hline 1986 & $\begin{array}{l}\text { Executive Order } 12564 \text { (Drug Free } \\
\text { Workplace Program) }\end{array}$ & $\begin{array}{l}\text { Directs all federal agencies to establish "drug- } \\
\text { free" workplaces and test "employees" in } \\
\text { "sensitive" positions; earmarks } \$ 56 \text { million for } \\
\text { first year of the program }\end{array}$ \\
\hline 1987 & $\begin{array}{l}\text { Mandatory Guidelines for Federal } \\
\text { Workplace Drug Testing } \\
\text { Programs }\end{array}$ & $\begin{array}{l}\text { Department of Health and Human Services } \\
\text { establishes scientific and technical standards for } \\
\text { lab certification and testing of federal } \\
\text { employees }\end{array}$ \\
\hline 1987 & Public Law 100-71 & $\begin{array}{l}\text { Specifies drugs for which federal employees may } \\
\text { be tested and establishes disclosure policy for } \\
\text { reporting of test results }\end{array}$ \\
\hline 1988 & Department of Defense Regulations & $\begin{array}{l}\text { Requires all defense contractors to test employees } \\
\text { with access to classified information or who } \\
\text { deal in matters of national security, health, or } \\
\text { safety (rules implemented by 1990) }\end{array}$ \\
\hline 1988 & $\begin{array}{l}\text { Department of Transportation } \\
\text { Regulations }\end{array}$ & $\begin{array}{l}\text { Requires all industries regulated by the } \\
\text { Department of Transportation to establish both } \\
\text { drug-testing and employee assistance programs }\end{array}$ \\
\hline 1988 & Drug-Free Workplace Act & $\begin{array}{l}\text { Requires all firms with federal contracts of } \\
\$ 25,000 \text { or more and all grantees to certify that } \\
\text { they provide drug-free workplaces }\end{array}$ \\
\hline 1989 & Nuclear Industry Regulations & $\begin{array}{l}\text { Requires licensees operating reactors to implemen } \\
\text { tests not only for illicit drugs but also for } \\
\text { alcohol, prescription drugs, and over-the-counter } \\
\text { medications }\end{array}$ \\
\hline 1991 & Omnibus Transportation Act & $\begin{array}{l}\text { Requires inclusion of alcohol in testing as well as } \\
\text { testing of intrastate transportation workers (rules } \\
\text { implemented by 1996) }\end{array}$ \\
\hline 1991 & Civil Space Employee Testing Act & $\begin{array}{l}\text { Requires alcohol and drug testing of all safety- } \\
\text { sensitive employees of NASA and its } \\
\text { contractors }\end{array}$ \\
\hline
\end{tabular}

Sources. -D. L. Ackerman, A History of Drug Testing, in Drug Testing: Issues and Options 3 (Robert H. Coombs \& Louis J. West eds. 1991); and Jacques Normand, Richard O. Lempert, \& Charles P. O'Brien eds., Under the Influence? Drugs and the American Work Force (1994).

"provisions for identifying illegal drug users." ${ }^{2}$ The directive explicitly called for the testing of employees in "sensitive" positions, suspected of drug use, involved in workplace accidents, or undergoing treatment in employee assistance programs (EAPs). The DFWP was immediately followed by a flurry of legislative and regulatory activity that reached beyond the public sector (see Table 1).

${ }^{2}$ See D. L. Ackerman, A History of Drug Testing, in Drug Testing: Issues and Options 3 (Robert H. Coombs \& Louis J. West eds. 1991). 
TABLE 2

Characteristics and Requirements of State Drug-Testing Laws

\begin{tabular}{ll}
\hline \hline States (Year) & \multicolumn{1}{c}{ Characteristics of Law } \\
\hline Louisiana (1987), Nebraska (1988), Utah (1987) & $\begin{array}{l}\text { Dismissal or other adverse action allowed } \\
\text { without recourse } \\
\text { Reasonable cause }\end{array}$ \\
Connecticut (1987), Tennessee (1988) & $\begin{array}{l}\text { Reasonable-cause testing with employee } \\
\text { assistance program or rehabilitation } \\
\text { option for first positive drug test }\end{array}$ \\
Iowa (1987), Minnesota (1987), Florida (1989), & $\begin{array}{l}\text { Reasonable cause with rehabilitation option; } \\
\text { Kansas (1988), Maine (1989) } \\
\text { preemployment for safety-sensitive } \\
\text { Montana (1987), Rhode Island (1987), criminal penalties for failure } \\
\text { Vermont (1987) }\end{array}$ \\
& to comply with laws \\
\hline
\end{tabular}

SourCES. - Richard R. Nelson, State Labor Legislation Enacted in 1987, 111 Monthly Lab. Rev. 38 (1988); Richard R. Nelson, State Labor Legislation Enacted in 1988, 112 Monthly Lab. Rev. 40 (1989); Richard R. Nelson, State Labor Legislation Enacted in 1989, 113 Monthly Lab. Rev. 35 (1990).

\section{A. State Drug-Testing Legislation}

In 1987 alone, more than half of all states debated, and seven passed, bills that established guidelines for workplace drug testing. By 1989, six more states had passed fairly comprehensive testing legislation. Although these statutes varied considerably in their approaches to dealing with employee drug use-with some states (Louisiana, Utah, and Nebraska) giving a green light to employers wishing to test any current employees and others (Montana, Vermont, and Rhode Island) banning testing except for those in positions that posed significant safety risks-all sanctioned reasonable-cause testing of employees in "safety-sensitive" positions such as trucking (see Table 2 for a breakdown of state laws). ${ }^{3}$

Unfortunately, there are few data on the extent of testing in trucking (or any other industry) before the passage of federal guidelines. That all states adopting testing legislation acknowledged the right of employers to screen workers in safety-sensitive positions, however, suggests that interest in drug testing this type of employee was high. ${ }^{4}$ By explicitly sanctioning the testing of such workers and drawing the legal boundaries around workplace testing, state laws cleared up what many in the trucking industry felt was a formidable barrier to the adoption of drug-testing programs, the "rapidly changing legal

${ }^{3}$ See Richard R. Nelson, State Labor Legislation Enacted in 1989, 113 Monthly Lab. Rev. 35 (1990). Today, employers use five main types of workplace testing programs: preemployment, random, postaccident, reasonable suspicion/cause, and routine scheduled or follow-up.

${ }^{4}$ In general, a "safety-sensitive" designation includes not only those in jobs that affect the public safety but also those in hazardous working environments or with fiduciary responsibilities. 
environment ... dealing with the rights and responsibilities of all parties involved in employee drug testing." ${ }^{5}$

By the end of 1988, firms in states that had clarified the conditions under which workplace testing was permitted were about twice as likely as all the rest to have EAPs, 24.2 versus 12.4 percent. ${ }^{6}$ Employee assistance programs generally provide counseling services for a host of problems including, though not limited to, substance abuse. ${ }^{7}$ Thus, drug-using truckers employed in states with testing laws were likely to be identified - if not by drug tests then by job performance reviews, colleague referrals, self-referrals, and so on-temporarily put out of service, and either directed toward treatment or dismissed. ${ }^{8}$ Although these states may have used means other than testing to identify illicit drug users, I refer to and group them in the analysis below as states that raised the likelihood that truckers were tested.

\section{B. The Department of Transportation's Drug-Testing Mandate}

At the federal level in 1988, the DOT, concerned by several highly publicized commercial truck, airplane, and train accidents, most notably the 1987 Conrail-Amtrak train crash that killed 16 and injured hundreds, devised testing requirements that applied to all its regulated private and public industries and affected more than 4 million private-sector employees. The mandate required preemployment, reasonable-cause, random, periodic, and postaccident drug testing of employees in safety-sensitive positions and stipulated that they be screened at a minimum for marijuana, cocaine, amphetamines, opiates, phencyclidine (commonly known as PCP or angel dust), and their metabolites. ${ }^{9}$ Although the regulations do not specify disciplinary actions,

${ }^{5}$ From Howard V. Hayghe, Anti-drug Programs in the Workplace: Are They Here to Stay? 114 Monthly Lab. Rev. 26 (1991).

${ }^{6}$ Bureau of Labor Statistics, Survey of Employer Anti-drug Programs (1989). In terms of employees, this translates into about 20 percent more workers in firms with EAPs. Estimates are based on Connecticut, Iowa, Minnesota, Montana, Rhode Island, and Vermont; Louisiana is not included.

${ }^{7}$ A 1991 national survey of full-time employees indicated that about 15 percent of respondents working in firms with EAPs had contacted the EAP about an employee they supervise and 8 percent had used it in the past for a problem of their own. Estimates suggest that on average 30 percent of EAP caseloads involve drug or alcohol abuse. See Jacques Normand, Richard O. Lempert, \& Charles P. O'Brien eds., Under the Influence? Drugs and the American Work Force (1994).

${ }^{8}$ Although this is seemingly complicated by the fact that truckers generally work away from home, the vast majority of truckers typically operate within 500 miles of home (75 percent in 1992) and more than half within 200 miles of home (57 percent in 1992). For statistics on distance from home, see table 1 in Thomas N. Hubbard, The Demand for Monitoring Technologies: The Case of Trucking, 115 Q. J. Econ. 533 (2000).

${ }^{9}$ This group of substances is often referred to as the NIDA-5, as they are the five drugs identified in the National Institute on Drug Abuse's testing guidelines. A 1991 act of Congress, the Omnibus Transportation Employee Testing Act (OTETA), required including alcohol in the screens, but this rule did not have to be implemented until 1995. 
such as dismissal, for positive drug tests, they do require that truckers be removed from duty until completion of a substance abuse prevention (SAP) program and a negative drug test. Those returning to duty must undergo a minimum of six follow-up tests per year for 1-5 years.

Each of the DOT's six agencies was responsible for tailoring the mandate to its covered industry. The Federal Highway Administration, which oversees the trucking industry, ruled that the 1988 mandate, which affected interstate truckers only, had to be implemented between the end of 1989 and the end of 1990, depending on the number of covered employees in the firm. ${ }^{10}$ As an article in the trucking trade journal Commercial Carrier Journal pointed out, most fleets were not testing either employees or applicants in $1988 .{ }^{11}$ Moreover, those trucking companies that screened for drugs prior to the passage of the DOT mandate were more likely to be in states with drugtesting legislation since these states had rates of testing that were 25-30 percent higher than the national average by the end of $1988 .{ }^{12}$ It is important to note that although rules affecting intrastate truckers were not put in place until 1995, many intrastate truckers were being tested after the earlier rules affecting interstate truckers took effect.

\section{Related Research}

The DOT's testing regulations undoubtedly played a role in the rapid diffusion of drug testing in the United States. By the beginning of 1993, 48 percent of private nonagricultural firms with more than 50 full-time employees had drug-testing programs, which represented a threefold increase in their incidence over 5 years. ${ }^{13}$ Despite this dramatic increase, there are few systematic studies of the relationship between drug testing and workplace outcomes. Perhaps the best, the landmark U.S. Postal Service Study, followed employees who were drug tested prior to employment but hired independently of drug test results. After an average of 1.3 years on the job, those who had tested positive for drugs at the time of initial employment had amassed a 60 percent higher mean absence rate (6.6 versus 4.1 percent of hours worked) and a 47 percent higher dismissal rate (15 versus 11 percent) than employees who tested negative. ${ }^{14}$ The study found no statistically significant differences in accidents or injuries, although this result may be a function of the particular

\footnotetext{
${ }^{10}$ Interstate truckers, who account for less than half of all truckers, are disproportionately involved in motor vehicle accidents. Between 1994 and 1996, they were involved in 72-75 percent of all truck crashes; the figures are similar for fatal truck crashes. The DOT's testing regulations had to be implemented by December 21, 1989, by employers with 50 or more covered employees and December 21, 1990, by all others.

${ }^{11}$ See Parry Desmond, Drug Screening, 145 Com. Carrier 85 (1988).

${ }^{12}$ See note 6 supra.

${ }^{13}$ See note 1 supra.

${ }^{14}$ See Jacques Normand, Stephen D. Salyards, \& John J. Mahoney, An Empirical Evaluation of Preemployment Drug Testing, 75 J. Applied Psychol. 629 (1990).
} 
work setting rather than any real differences between those who tested positive and those who did not.

Stephen Mehay and Rosalie Pacula performed the only study, to my knowledge, that rigorously analyzes the effects of workplace testing on drug use. ${ }^{15}$ They looked at the deterrence effect of an aggressive random drug-testing policy implemented by the military in 1981 and concluded that after the introduction of their program, military personnel were about 20 percent less likely to report past-year drug use than civilians, other factors held constant at their means. Moreover, they attribute about 30 percent of this difference to the deterrence effect of the testing program itself.

The data used, however, do not enable the authors to link these findings to outcomes such as accidents. In addition, the data are self-reported. Given the military's harsh penalties for drug use, these figures are probably significantly underreported relative to the general population. Nonetheless, this work is the first systematic attempt at measuring the deterrence effects of drug testing, a relationship that is particularly important if drug use has a causal effect on outcomes. ${ }^{16}$

\section{The Effect of Drug Testing in the Trucking Industry}

Understanding the impact of drug testing in the motor carriage industry requires some knowledge of the relationship between trucking companies and drivers. ${ }^{17} \mathrm{~A}$ key feature of this relationship is that it is subject to classic principal-agent problems. Whereas carriers maximize profits, drivers maximize utility, which is decreasing in effort, increasing in income, and, at least for some, nondecreasing in drug use. On-time and damage-free arrival, an important component of production, requires effort and thus conflicts with the objectives of the driver. Trucking companies deal with this in part by making compensation, job assignments, and even continued employment a function of arrival times and driving records. Since drivers do not bear the full cost of their driving, performance incentives, even if set optimally, may actually increase driving variability within a haul. Truckers may prefer to achieve on-time arrivals by taking longer breaks and then speeding and stopping less frequently to make up time. This in turn may encourage drug

\footnotetext{
${ }^{15}$ See Stephen L. Mehay \& Rosalie Liccardo Pacula, The Effectiveness of Workplace Drug Prevention Policies: Does “Zero Tolerance” Work? (Working Paper No. 7383, Nat'l Bur. Econ. Res., October 1999).

${ }^{16}$ Few studies provide conclusive evidence of the relationship between workplace accidents and drug use itself. A recent exception is Robert Kaestner \& Michael Grossman, The Effects of Drug Use on Workplace Accidents, 5 Lab. Econ. 267 (1999).

${ }^{17}$ This section draws largely on Hubbard, supra note 8.
} 
use, particularly the use of stimulants, in order to maintain such schedules. ${ }^{18}$ Independent of any effect drug use may have on driving ability, drug testing may be one way in which carriers limit erratic, within-haul, driving.

If drug testing encourages safer driving patterns, then, all else equal, the number and/or severity of truck accidents should have decreased after the passage of state drug-testing laws and the DOT mandate. To assess this, I would like to look at trends in all accidents, fatal and nonfatal. Unfortunately, the methods used to estimate nonfatal accidents were revised between 1987 and 1988, just prior to the implementation of drug-testing regulations, making the pre- and posttesting series difficult to compare. As a result, almost all studies of highway safety restrict their analysis to trends in fatal accidents. ${ }^{19}$ Limiting the analysis to fatal crashes, which account for less than .5 percent of all reported crashes and 2 percent of those reported with injuries, causes an obvious problem. It ignores changes in the distribution of accident severity that were caused by the traffic safety mandate itself. On the other hand, samples of nonfatal accidents may suffer serious selection bias. Mandated drug testing created incentives for truckers, even those not "under the influence," to settle minor accidents on their own so as to avoid the hassle of undergoing postaccident testing. As less serious accidents were more likely to go unreported after the mandate, nonfatal accident data could be biased toward more serious accidents and the analysis away from finding an effect. By relying on fatal accident data, which are collected by census, I avoid these potentially troubling selection issues.

To analyze trends in fatal accidents, I use the Fatal Accident Reporting System (FARS). The primary source of traffic fatality data in the United States, FARS is a census of all vehicles and people involved in fatal motor vehicle accidents. Federal law requires local police departments to submit crash information on all such accidents. Although the law has been in effect since at least 1975 , compliance was spotty until $1983 .{ }^{20}$ As a result, the analysis of state fatalities looks only at the period between 1983 and 1998 .

\footnotetext{
${ }^{18}$ A 1986 study of drug use in 317 randomly selected truckers in Tennessee by the Insurance Institute for Highway Safety found 12 percent using stimulants, roughly 7 times the percentage of Americans 12 and over using in the past year and almost double the percent ever using. See John D. Schulz, Roadside Government Drug Tests for Truck Drivers Asked by ATA, 215 Traffic World 17 (1988). Another study identified fatigue and then alcohol and drug use as the primary causes of fatal truck accidents between 1987 and 1988. See I. Rosenfeld, Fatigue, Alcohol, and Drugs Identified as Prime Causes of Fatal Truck Accidents, 221 Traffic World 13 (1990).

${ }^{19}$ See, for example, Christopher J. Ruhm, Alcohol Policies and Highway Vehicle Fatalities, 14 J. Health Econ. 435 (1996); Steven D. Levitt \& Jack Porter, How Dangerous Are Drinking Drivers? 109 J. Pol. Econ. 1198 (2001); Thomas S. Dee \& William N. Evans, Teens and Traffic Safety, in Risky Behavior among Youths: An Economic Analysis 121 (J. Gruber ed. 2001).

${ }^{20}$ See Levitt \& Porter, supra note 19.
} 


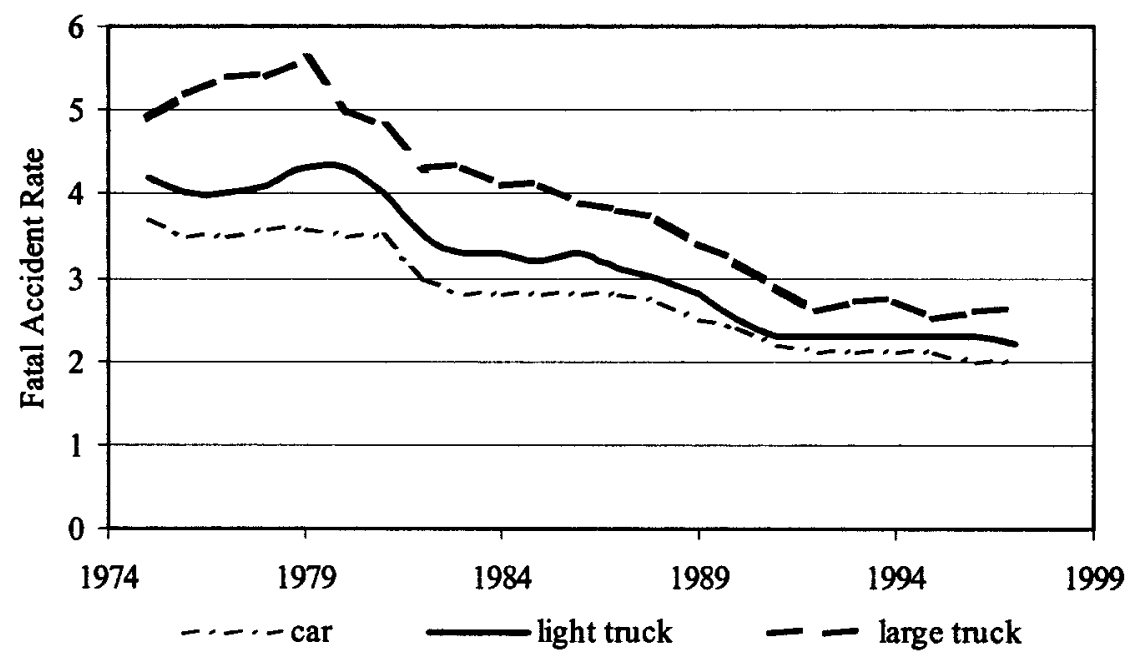

FIGURE 1.-Fatal accidents per 100 million vehicle miles traveled, by vehicle type: 1975-97

National trends are presented for intervals between 1975 and 1998 because these "reporting errors" are less likely to affect the results. ${ }^{21}$

\section{National Trends in Fatal Truck Accidents}

As noted above, fatal motor vehicle accidents provide the best source of information on long-run trends in highway safety. Figure 1 considers fatal accident involvement per vehicle mile traveled (VMT) between 1975 and 1996 for cars, light trucks, and large trucks. ${ }^{22}$ As measured by vehicle miles traveled, the three series have remarkably similar trends. More important, the decrease in truck involvement rates does not differ significantly from the other series after the 1988 announcement of the DOT mandate or the 1990 implementation of drug testing. In other words, using a test of structural change, I cannot reject at the 5 percent level the hypothesis that there has been no change in trends in fatal truck crashes relative to car crashes per VMT in 1988,1989 , or $1990 .{ }^{23}$ Broad changes in traffic safety that occurred over this period, however, may mask any effect of testing on truck accident fatality rates. Fortunately, I can call on additional evidence from statewide variation in the adoption of drug-testing laws to sort out confounding factors.

${ }^{21}$ The choice of interval is based on the availability of data on vehicle miles traveled.

${ }^{22}$ Light trucks include pickups, vans, minivans, utility vehicles, campers, and motor homes weighing 26,000 pounds or less. They do not include buses.

${ }^{23}$ The test run is of the form Truck Fatality Rate $=\alpha+\beta_{1}($ Car Fatality Rate $)+$ $\beta_{2}$ Trend $+\mu$, and null hypothesis: $\beta_{2}($ Premandate $)=\beta_{2}($ Postmandate $)$. 


\section{Truck Accidents across States: Current and Prospective}

In this section, I exploit state drug-testing laws along with the DOT mandate as exogenous sources of variation in the likelihood that truckers were tested across states as well as over time. As discussed in greater detail below, because of how few fatal truck accidents occur in any given state and year, I focus on the effects of testing on state accident fatalities as a function of vehicle miles traveled rather than on fatal accident rates or rates of accident fatalities. Adding state laws into the analysis allows me to use year fixed effects to control for aggregate trends in accident fatalities and helps isolate the effect of testing from coincident national efforts to increase truck safety such as enforcement of hours-of-service regulations, design improvements in seat belts and truck cabs, and the establishment of uniform commercial driver's license requirements. ${ }^{24}$ In addition, it lets me use state fixed effects to control for long-run state differences in fatal accident trends.

State and year fixed effects cannot control for state-specific highway safety changes that occurred during the period under study. Because state traffic safety campaigns tend to be initiated by federal incentive schemes, however, these programs - seat-belt laws, speed limits, and "driving under the influence laws"- are relatively easy to identify and control for in the regression analysis below. ${ }^{25}$ Where possible, I also include linear, state-specific time trends to control for any preexisting state trends in accident fatalities that are correlated with the adoption of drug-testing laws. Thus, the results presented here should capture changes owing to state and federal drug-testing programs, not other safety innovations or preexisting state trends.

I use FARS data to generate the fatality counts for all traffic accidents as well as two subgroups, car and large-truck accidents, in a given state and year between 1983 and 1998. In addition to categorizing states by their drugtesting legislation, which along with the federal mandate creates the variation in the probability that truckers were tested, I classify them by other determinants of traffic safety (see the Data Appendix for their source and definition). These include state fuel taxes, mandatory seat-belt laws (which between 1984 and 1998 were adopted by all states except New Hampshire), policies to prevent drunk driving (such as lowering the legal driving blood alcohol concentration to .08 percent), maximum speed limits of 65 miles per hour (which were adopted along rural interstates by many states during the late 1980s), and, beginning in 1995, speed limits of 70 miles per hour and

\footnotetext{
${ }^{24}$ These safety improvements were all introduced by the DOT and implemented at the national level.

${ }^{25}$ See Robert Crandall, Howard W. Gruenspecht, \& Theodore Kecker, Regulating the Automobile (1986); and D. Vinzant, State Highway Safety Legislation (1994).
} 
above. ${ }^{26}$ Since traffic fatalities are procyclic, I also control for state unemployment rates. ${ }^{27}$

\section{A. Specification of State Accident Fatalities}

Reduced-form econometric models of traffic fatalities generally express fatality rates per vehicle miles traveled or population size. ${ }^{28}$ Using such rates for this analysis presents a problem because in many years there are relatively few large-truck accident fatalities by state. In a fifth of all state years, there were fewer than 25 large-truck accident fatalities. To avoid introducing considerable noise into the analysis, I exploit the nonnegative count nature of the fatality data, while allowing for a more flexible functional form than the more commonly used Poisson model. ${ }^{29}$ Specifically, I estimate a conditional maximum-likelihood negative binomial model of the form

$$
\text { Fatalities }_{s t}=F\left(D_{s t}, X_{s t}, q_{s}, g_{t}\right) \text {, }
$$

where $s$ indicates state, $t$ indicates year, $F(\cdot)$ is a negative binomial, $q_{s}$ and $g_{t}$ are state and year fixed effects, and $X_{s t}$ is a vector of state-level traffic safety characteristics in year $t$. The natural logarithm of VMT enters as an independent regressor in these estimations. The estimates from the conditional maximum likelihood negative binomial models are expressed as the percentage change in the given fatality count. ${ }^{30}$

\footnotetext{
${ }^{26}$ The federal government established a maximum speed limit of 55 miles per hour in 1977 in response to the oil crisis. In 1987 these regulations were relaxed, and in that year alone, 38 states raised their speed limits. The evidence on these increases is mixed, although this analysis suggests that raising the speed limit to 70 miles per hour or more made highways more dangerous.

${ }^{27}$ See William N. Evans \& John D. Graham, Traffic Safety and the Business Cycle, 4 Alcohol Drugs \& Driving 31 (1988); Christopher J. Ruhm, Are Recessions Good for Your Health? 115 Q. J. Econ. 617 (2000).

${ }^{28}$ See Ruhm, supra note 19, for examples of both.

${ }^{29}$ The Poisson regression model (PRM) imposes equality of the conditional mean and variances of occurrences, a feature inconsistent with a general tendency toward overdispersion. Using the PRM when there is overdispersion, as there is here, leads to inefficient estimates, downward-biased standard errors, and thus spuriously large $z$-statistics. The negative binomial model (NB), essentially a PRM with unobserved heterogeneity introduced by a gammadistributed error term, is a more flexible functional form. See J. Scott Long, Regression Models for Categorical and Limited Dependent Variables (1997). Jerry A. Hausman, Bronwyn H. Hall, $\&$ Zvi Griliches, Econometric Models for Count Data with an Application to the Patents-R\&D Relationship, 52 Econometrica 909 (1984), pioneered the approach. See Dee, supra note 19, for its use in analyzing accident fatalities.

${ }^{30}$ Since the mean of the dependent variable in a binomial regression model is parameterized as $\mu_{i}=\exp \left(X_{i}^{\prime} \beta\right)$, the percentage change in expected fatalities from adopting a drug-testing law (or from a unit change in a continuous variable such as the unemployment rate) is given by $100\left[\exp \left(\beta_{k}\right)-1\right]$.
} 
Estimates using a more intuitive log-linear specification,

$$
\log \left(\frac{\text { Fatalities }}{100 \text { million VMT }}\right)_{s t}=\alpha D_{s t}+\beta X_{s t}+q_{s}+g_{t}+\mu_{s t}
$$

are also presented as a specification check. In all specifications, fatalities from three accident types are studied-all, car, and truck. Fatalities from all accidents include deaths from any vehicle crashes. In contrast, car accident fatalities include deaths from crashes involving only cars or utility vehicles. In other words, deaths from crashes between cars and trucks (or vans or buses) are excluded. This exclusion is made so that the effect of drug testing on truck accident fatalities can be checked against car accident fatalities; arguably, the latter group should be unaffected by the DOT testing mandate. ${ }^{31}$ Standard errors are corrected to allow for correlation in the error terms at the state level. ${ }^{32}$

The variable of interest, $D_{s t}$, is an indicator of drug testing equal to one in state $s$ in the year $t$ it adopted testing legislation and every year thereafter or, if that state did not pass legislation prior to 1990, equal to one in 1990, the year the DOT mandate had to be implemented, and every year thereafter. Note that $D_{s t}$ captures the year of adoption of state laws but the year of implementation, as opposed to announcement, of the federal mandate. This difference in coding is necessary in order to exploit the cross-sectional variation in the likelihood that truckers were being tested. I look at the entire period, for 1983-98, as well as the period before the federal mandate took effect, 1983-89. Over the full period, I also include state-specific linear time trends. Unfortunately, I cannot use these in the analysis of the premandate era without significant loss of power. I also look at the "reverse experiment," which compares the differential effect of the federal mandate on states that did not have testing legislation prior to 1990 relative to those that did. ${ }^{33}$ In other words, this specification considers a federal mandate indicator, equal to one in years after and including 1990 only if a state had not previously passed testing legislation and equal to zero in all years prior to 1990.

\section{B. State Panel Results}

The results in Tables 3,4 , and 5 strongly suggest that drug testing improved "workplace outcomes" in the trucking industry. Tables 3 and 4 use the preferred negative binomial specification. Table 3 limits the analysis to the

\footnotetext{
${ }^{31}$ To the extent that the mandate was part of a broader agenda (see Table 1) and thus captures testing regulations affecting other parts of the workforce, it may have "an effect" on car fatalities.

${ }^{32}$ See Marianne Bertrand, Esther C. Duflo, \& Sendhil Mullainathan, How Much Should We Trust Differences-in-Differences Estimates? (Working Paper No. 8841, Nat'l Bur. Econ. Res., March 2002).

${ }^{33}$ The "reverse experiment" follows Jonathan Gruber, The Incidence of Mandated Maternity Benefits, 84 Am. Econ. Rev. 622 (1994)
} 
TABLE 3

Negative Binomial Models of State Motor Vehicle Accidents: Percentage Change in Traffic Fatalities in Premandate Period, 1983-89

\begin{tabular}{|c|c|c|c|c|}
\hline Independent Variable & Mean & All & Cars & Trucks \\
\hline Drug-testing legislation & .093 & -3.30 & $(.36)$ & $-9.88^{+}$ \\
\hline Fuel tax & .133 & -.21 & $-.17 \quad(.47)$ & $-1.42 *$ \\
\hline Mandatory seat-belt laws & .347 & -1.87 & $-3.79 * *(2.99)$ & -5.18 \\
\hline Speed limit of 65 miles per hour & .362 & $1.11 \quad(.59)$ & $-.26 \quad(.12)$ & 1.29 \\
\hline BAC limit of .08 & .047 & $-5.02 * *(2.95)$ & $-14.4 * * \quad(8.56)$ & $43.2 * * \quad(10.1)$ \\
\hline Unemployment rate & 7.05 & $-2.34 * *(4.12)$ & $-1.99 * *(3.47)$ & $-5.11 * * \quad(4.58)$ \\
\hline \multicolumn{5}{|l|}{ Mean dependent variable: } \\
\hline $\begin{array}{l}\text { Number of fatalities, } \\
\text { year by state }\end{array}$ & & 914 & 442 & 119 \\
\hline
\end{tabular}

NotE. - Absolute values of $z$-statistics for estimated coefficients are reported in parentheses. Standard errors are clustered at the state level to correct for serial correlation in accidents. BAC: Blood alcohol concentration. All models are estimated using 343 observations (all states except Hawaii over 7 years) and include state and year fixed effects and the natural log of total vehicle miles traveled (VMT). Hawaii and the District of Columbia are excluded because of limited data on VMT. Car accident fatalities include fatalities in accidents involving cars or utility vehicles but not trucks, vans, or buses. Deaths from crashes between cars and trucks are excluded. Effects represent the percentage change in expected fatality counts from making a discrete change to a given policy or a unit change in a continuous variable such as the unemployment rate, all other variables held constant. The drug-testing indicator equals one in state $s$ in the year it adopted drug-testing legislation and every year thereafter. States with legislation are, in order of passage, Connecticut, Iowa, Louisiana, Minnesota, Montana, Rhode Island, Vermont, Utah, Nebraska, Kansas, Tennessee, Florida, and Maine.

+ Significant at the $10 \%$ level.

* Significant at the $5 \%$ level.

** Significant at the $1 \%$ level.

premandate period. It shows a roughly 10 percent decrease in truck accident fatalities, even after controlling for a broad set of traffic safety factors, in states that passed drug-testing legislation relative to those that did not. The effect of testing in trucking may also drive the 3 percent decrease in total traffic accident fatalities. In contrast, testing prior to the 1990 mandate had no detectable effect on car accident fatalities. This lends considerable support to the claim that drug testing instead of general changes in traffic safety led to the decrease in truck accident fatalities in states that clarified the legal boundaries of employee drug testing and sanctioned the testing of safetysensitive workers such as truckers.

Table 4 looks at the entire period, 1983-98, and, within each fatality category, reports results both with and without state-specific trends. Both specifications reveal a roughly 9 percent decrease in truck accident fatalities, even after controlling for traffic safety factors, in states that passed drugtesting legislation or implemented the federal testing mandate relative to those that did not. Put another way, drug testing is associated with an average annual reduction of almost 11 fatalities per state. Table 4 also shows a roughly 2 percent (although statistically indistinguishable from zero) decrease in car accident fatalities over the whole period. Note, however, that any declines in car accident fatalities occurred in the postmandate period, after a broader 
TABLE 4

Conditional Maximum-Likelihood Negative Binomial Models of State Motor Vehicle Accidents: Percentage Change in Traffic Fatalities, 1983-98

\begin{tabular}{|c|c|c|c|c|c|c|c|}
\hline \multirow[b]{2}{*}{ INDEPENDENT VARIABLE } & \multirow[b]{2}{*}{ Mean } & \multicolumn{2}{|c|}{ ALL } & \multicolumn{2}{|c|}{ CARS } & \multicolumn{2}{|c|}{ TRUCKS } \\
\hline & & No Trend & Trend & No Trend & Trend & No Trend & Trend \\
\hline Drug-testing legislation & .603 & $\begin{array}{c}-3.00 \\
(1.45)\end{array}$ & $\begin{array}{c}-2.70 \\
(1.39)\end{array}$ & $\begin{array}{r}-2.01 \\
(.67)\end{array}$ & $\begin{array}{c}-.52 \\
(.18)\end{array}$ & $\begin{array}{c}-9.21 * \\
(2.14)\end{array}$ & $\begin{array}{c}-9.39 * \\
(2.05)\end{array}$ \\
\hline Fuel tax & .165 & $\begin{array}{l}-.58^{*} \\
(2.44)\end{array}$ & $\begin{array}{l}-.47^{*} \\
(2.01)\end{array}$ & $\begin{array}{l}-.32 \\
(1.43)\end{array}$ & $\begin{array}{l}-.33 \\
(1.39)\end{array}$ & $\begin{array}{c}-1.26^{* *} \\
(3.01)\end{array}$ & $\begin{array}{c}-1.07^{*} \\
(2.18)\end{array}$ \\
\hline Mandatory seat-belt laws & .652 & $\begin{array}{r}-1.15 \\
(.83)\end{array}$ & $\begin{array}{c}-2.40 * \\
(2.24)\end{array}$ & $\begin{array}{c}-.33 \\
(.23)\end{array}$ & $\begin{array}{c}-2.40^{*} \\
(2.18)\end{array}$ & $\begin{array}{c}-5.80 * * \\
(2.71)\end{array}$ & $\begin{array}{c}-5.26 \\
(2.31)\end{array}$ \\
\hline $\begin{array}{l}\text { Speed limit of } 70+\text { miles } \\
\text { per hour }\end{array}$ & .092 & $\begin{array}{l}13.1 * * \\
(4.41)\end{array}$ & $\begin{array}{c}5.43^{*} \\
(2.06)\end{array}$ & $\begin{array}{l}12.5^{* *} \\
(4.25)\end{array}$ & $\begin{array}{c}5.34^{+} \\
(4.25)\end{array}$ & $\begin{array}{l}14.6 * * \\
(4.18)\end{array}$ & $\begin{array}{l}15.9 \\
(3.01)\end{array}$ \\
\hline BAC limit of .08 & .131 & $\begin{array}{r}-2.15 \\
(.83)\end{array}$ & $\begin{array}{l}.13 \\
(.56)\end{array}$ & $\begin{array}{c}-2.09 \\
(1.00)\end{array}$ & $\begin{array}{c}.98 \\
(.36)\end{array}$ & $\begin{array}{l}3.40 \\
(.91)\end{array}$ & $\begin{array}{r}-2.36 \\
(.58)\end{array}$ \\
\hline Unemployment rate & 6.27 & $\begin{array}{c}-2.83^{* *} \\
(5.45)\end{array}$ & $\begin{array}{c}-2.17 * * \\
(5.34)\end{array}$ & $\begin{array}{c}-2.39 * * \\
(3.84)\end{array}$ & $\begin{array}{c}-2.36^{* *} \\
(3.84)\end{array}$ & $\begin{array}{c}-3.93^{* *} \\
(4.57)\end{array}$ & $\begin{array}{c}-3.62^{* *} \\
(3.64)\end{array}$ \\
\hline $\begin{array}{l}\text { Mean dependent variable: } \\
\text { Number of fatalities, } \\
\text { year by state }\end{array}$ & & & & & & & \\
\hline
\end{tabular}

NoTE. - Absolute values of $z$-statistics for estimated coefficients are reported in parentheses. Standard errors are clustered at the state level to correct for serial correlation in accidents. BAC: Blood alcohol concentration. All models are estimated using 784 observations (all states except Hawaii over 16 years) and include state and year fixed effects and natural logs of vehicle miles traveled. "Trend" columns show models that also include state-specific linear time trends. Car accident fatalities include fatalities in accidents involving cars or utility vehicles but not trucks, vans, or buses. Deaths from crashes between cars and trucks are excluded. Effects represent the percentage change in expected fatality counts from making a discrete change to a given policy or a unit change in a continuous variable such as the unemployment rate, all other variables held constant. The drug-testing indicator equals one in state $s$ in the year it adopted drugtesting legislation and every year thereafter or, if that state did not pass legislation passed prior to 1990, equals one in the year the Department of Transportation mandate had to be implemented and every year thereafter. States with legislation are, in order of passage, Connecticut, Iowa, Louisiana, Minnesota, Montana, Rhode Island, Vermont, Utah, Nebraska, Kansas, Tennessee, Florida, and Maine.

+ Significant at the $10 \%$ level.

* Significant at the $5 \%$ level.

** Significant at the $1 \%$ level

set of substance abuse legislation was passed at the federal level. Moreover, including state-specific time trends considerably reduces the estimated effect on car accident fatalities. Analysis of the dynamics of accident fatalities (below) further suggests that this car "effect" may be driven by preexisting state trends.

Table 5, which uses the more intuitive log-linear specification of fatality rates, is presented primarily as a specification check. It presents the coefficients on the drug-testing indicator in both the premandate and full periods. All the traffic safety covariates used in Tables 3 and 4 are included in the regressions; state trends are included in the analysis of the full sample period. As mentioned previously, this specification adds considerable noise to the analysis (and as a result is not used in the remaining tables). Nonetheless, consistent with the estimates in Tables 3 and 4, these specifications reveal, in both the premandate and full periods, a roughly 9-10 percent decrease in 
TABLE 5

Robustness Check: Percentage Change in Rates of Accident Fatalities in Premandate Period, 1983-89, and over the Full Sample Period, 1983-98

\begin{tabular}{|c|c|c|c|c|c|c|c|}
\hline Independent Variable & Mean & \multicolumn{2}{|c|}{ All } & \multicolumn{2}{|c|}{ Cars } & \multicolumn{2}{|c|}{ Trucks } \\
\hline \multirow{5}{*}{$\begin{array}{l}\text { Premandate period, } 1983-89 \text { : } \\
\text { Drug-testing legislation } \\
\text { Mean fatalities per } 100 \text { million } \\
\text { VMT, year by state }\end{array}$} & \multirow{5}{*}{.093} & \multirow{2}{*}{\multicolumn{2}{|c|}{$-4.49 *(2.00)$}} & \multirow{2}{*}{\multicolumn{2}{|c|}{$-.42(.17)$}} & \multirow{2}{*}{\multicolumn{2}{|c|}{$-8.78(1.27)$}} \\
\hline & & & & & & & \\
\hline & & \multicolumn{2}{|c|}{31.6} & \multicolumn{2}{|c|}{15.9} & \multicolumn{2}{|c|}{3.88} \\
\hline & & \multicolumn{2}{|c|}{ AlL } & \multicolumn{2}{|c|}{ CARS } & \multicolumn{2}{|c|}{ Trucks } \\
\hline & & No Trend & Trend & No Trend & Trend & No Trend & Trend \\
\hline \multicolumn{8}{|l|}{ Full sample period, 1983-98: } \\
\hline Drug-testing legislation & .603 & $\begin{array}{c}-3.48 \\
(1.46)\end{array}$ & $\begin{array}{r}-3.70^{+} \\
(1.74)\end{array}$ & $\begin{array}{r}-2.02 \\
(.72)\end{array}$ & $\begin{array}{r}-1.34 \\
(.47)\end{array}$ & $\begin{array}{r}-8.86^{+} \\
(1.79)\end{array}$ & $\begin{array}{r}-9.58^{+} \\
(1.80)\end{array}$ \\
\hline \multicolumn{8}{|l|}{ Mean fatalities per 100 million } \\
\hline VMT, year by state & & 25.6 & 25.6 & 12.2 & 12.2 & 3.12 & 3.12 \\
\hline
\end{tabular}

Note. - Absolute values of $t$-statistics for estimated coefficients are reported in parentheses. Standard errors are clustered at the state level to correct for serial correlation in accidents. Models estimated over the entire period include 784 observations (all states except Hawaii over 16 years). Models estimated prior to the Department of Transportation mandate include 343 observations (all states except Hawaii over 7 years, 1983-89). All include state and year fixed effects, are weighted by state population, and control for the traffic safety factors shown in Tables 3 and 4: state fuel taxes, seat-belt laws, speed limits, blood alcohol concentration limits, and state unemployment rates. "Trend" columns show models that also include statespecific linear time trends. Rates are defined as fatalities per 100 million vehicle miles traveled (VMT). Hawaii and the District of Columbia are excluded because of limited data on VMT. Car accident fatalities include fatalities in accidents involving cars or utility vehicles but not trucks, vans, or buses. Deaths from crashes between cars and trucks are excluded. Effects represent the percentage change in fatality rates from adopting drug-testing legislation. The drug-testing indicator equals one in state $s$ in the year it adopted drug-testing legislation and every year thereafter. States with legislation are, in order of passage, Connecticut, Iowa, Louisiana, Minnesota, Montana, Rhode Island, Vermont, Utah, Nebraska, Kansas, Tennessee, Florida, and Maine.

+ Significant at the $10 \%$ level.

* Significant at the $5 \%$ level.

truck accident fatality rates. Similarly, they show that at least in the premandate period, the period before any significant testing occurred in the workplace, state drug-testing laws had little effect on car accident fatalities. In summary, Table 5 suggests that the estimates in Tables 3 and 4 are not driven by the choice of functional form. ${ }^{34}$

Table 6 reports the results of the "reverse experiment," which uses existing

${ }^{34}$ As a further specification check, Appendix Table A2 compares the negative binomial and log-linear results for the sample of geographically large states (those greater than 55,000 square miles in area, larger than the median state). Since large states have roughly 10 percent more accident fatalities per year, the difference in precision between the two models narrows considerably. Moreover, since many of the truckers in these states are intrastate, these results support the claim made by many trucking companies that once they started testing some truckers, they opted to test them all (inter- and intrastate drivers). A final point to note is that the magnitude of the drug-testing effect is considerably larger here than in the full sample. Since state laws covered only workers employed by establishments in that state, this sample may give cleaner estimates of the impact of testing. In other words, this sample reduces the inclusion of fatalities that involved drivers not subject to testing but passing through states that allowed testing as well as those subject to testing but passing through states without testing laws. Irrespective of one's interpretation of the increase in magnitude, what is taken away is clear. The estimated effect of drug testing on highway safety is not driven by the choice of functional form. Drug testing appears to have reduced truck accident fatalities. 
TABLE 6

"Reverse Experiment," Comparative Effect of Federal Mandate on State Traffic Fatalities: Percentage Change in Traffic Fatalities, 1983-98

\begin{tabular}{|c|c|c|c|c|c|c|c|}
\hline \multirow[b]{2}{*}{ INDEPENDENT VARIABLE } & \multirow[b]{2}{*}{ Mean } & \multicolumn{2}{|c|}{ AlL } & \multicolumn{2}{|c|}{ CARS } & \multicolumn{2}{|c|}{ TRUCKS } \\
\hline & & No Trend & Trend & No Trend & Trend & No Trend & Trend \\
\hline Federal testing mandate & .419 & $\begin{array}{c}-3.26 \\
(1.36)\end{array}$ & $\begin{array}{c}2.86 \\
(1.25)\end{array}$ & $\begin{array}{r}-3.28 \\
(.96)\end{array}$ & $\begin{array}{c}3.66 \\
(1.07)\end{array}$ & $\begin{array}{c}-9.93^{*} \\
(2.15)\end{array}$ & $\begin{array}{r}-8.44 \\
(1.30)\end{array}$ \\
\hline $\begin{array}{l}\text { Testing laws } \\
\text { (reverse experiment) }\end{array}$ & .183 & $\begin{array}{c}-2.51 \\
(1.18)\end{array}$ & $\begin{array}{r}-6.42 * \\
(2.37)\end{array}$ & $\begin{array}{l}.13 \\
(.05)\end{array}$ & $\begin{array}{c}-3.32 \\
(1.00)\end{array}$ & $\begin{array}{r}-8.00 \\
(1.31)\end{array}$ & $\begin{array}{r}-10.0 \\
(1.61)\end{array}$ \\
\hline Mean dependent variable & & 872 & 872 & 397 & 397 & 113 & 113 \\
\hline
\end{tabular}

NotE. - Absolute values of $z$-statistics for estimated coefficients are reported in parentheses. Standard errors are clustered at the state level to correct for serial correlation in accidents. All models are estimated using 784 observations (all states except Hawaii over 16 years) and include state and year fixed effects and the natural log of total vehicle miles traveled (VMT). Hawaii and the District of Columbia are excluded because of limited data on VMT. "Trend" columns show models that also include state-specific linear time trends. Car accident fatalities include fatalities in accidents involving cars or utility vehicles but not trucks, vans, or buses. Deaths from crashes between cars and trucks are excluded. In the reverse experiment, the federal mandate indicator equals one in years after and including 1990 only if a state had not passed drugtesting legislation prior to the implementation of the federal mandate. It equals zero in all years prior to 1990. A state law indicator, equal to one in the year a state adopted testing legislation and thereafter, controls for the initial effects of the state experiments. Two separate dummies, one for the laws and the other for the mandate, are used to capture the effects of both types of changes in testing policies in a single regression. Effects represent the percentage change in expected fatality counts from making a discrete change to a given policy, all other variables held constant.

* Significant at the $5 \%$ level.

state laws as controls to study the effect of the federal mandate on truckers in states that had not passed drug-testing legislation. It uses the same basic regression framework as above but includes a federal mandate indicator, equal to one in years after and including 1990 only if a state had not previously passed testing legislation and equal to zero in all years prior to 1990. To control for the initial effects of the state experiments, I also include a state law indicator, equal to one in the year a state adopted drug-testing legislation and thereafter. This reverse experiment, which uses states that passed legislation as "control" states over the entire period and those that did not pass legislation as "treatment" states once the mandate was implemented, allows me to isolate the effect of the mandate on the average state without an early testing law. Relative to states that already had testing legislation in place, states that were not testing prior to the 1990 implementation of the rigorous DOT drug-testing program experienced slightly higher average declines in truck accident fatalities, approximately 10 versus 8 percent per year. Note, however, that these magnitudes flip when state-specific time trends are included. Moreover, in neither specification is this difference statistically distinguishable from zero, which suggests that there was little added value to mandating rather than simply defining the legal boundaries of drug testing in the trucking industry.

Table 7 explores the dynamics of the relationship between drug testing 
TABLE 7

Conditional Maximum Likelihood Negative Binomial Models of State Motor Vehicle Accident Fatalities: Lead and Lag Specifications, 1983-98

\begin{tabular}{lccc}
\hline \hline Drug-Testing Legislation & All & Cars & Trucks \\
\hline Before implementation of federal transportation & & & \\
mandate, 1983-89: & -.53 & -.68 & -2.94 \\
2 years before passage & $(.26)$ & $(.29)$ & $(.55)$ \\
& .58 & 1.96 & -2.27 \\
1 year before passage & $(.20)$ & $(.70)$ & $(.29)$ \\
Year of passage & -3.20 & .36 & -10.3 \\
& $(.87)$ & $(.19)$ & $(.99)$ \\
1 year after passage & -2.23 & 4.00 & -17.3 \\
& $(.44)$ & $(.88)$ & $(1.45)$ \\
$2+$ years after passage & -4.62 & 3.26 & -11.0 \\
& $(.72)$ & $(.59)$ & $(.69)$ \\
Entire sample period, 1983-98: & & & \\
2 years before implementation & -.52 & -3.14 & -2.30 \\
& $(.32)$ & $(1.32)$ & $(.46)$ \\
1 year before implementation & -.74 & -3.66 & .00 \\
& $(.29)$ & $(1.39)$ & $(.01)$ \\
Year of implementation & -3.52 & -5.67 & -7.03 \\
& $(1.18)$ & $(1.23)$ & $(.91)$ \\
1 year after implementation & -2.74 & -3.89 & $-14.2^{+}$ \\
& $(.72)$ & $(.73)$ & $(1.66)$ \\
$2+$ years after implementation & $-8.53 *$ & $-9.64^{+}$ & -8.89 \\
& $(1.96)$ & $(1.75)$ & $(.96)$ \\
\hline
\end{tabular}

NotE. - Absolute values of $z$-statistics for estimated coefficients are reported in parentheses. Standard errors are clustered at the state level to correct for serial correlation in accidents. Models estimated over the entire period include 784 observations (all states except Hawaii over 16 years) and include state and year fixed effects and the natural logs of vehicle miles traveled. Models estimated prior to the Department of Transportation mandate include 343 observations (all states except Hawaii over 7 years, 1983-89). All indicators are mutually exclusive. The " $2+$ " indicator captures years after the law or mandate, starting from year 2. See the text for the definition of the other indicators. Estimates are relative to the third-year lag. Effects represent the percentage change in expected fatality counts from making a discrete change to a given policy, all other variables held constant.

+ Significant at the $10 \%$ level

* Significant at the $5 \%$ level.

and the reductions in accident fatalities. Did these reductions precede the implementation of drug testing? If so, attributing improvements in highway safety to testing may be specious. If not, was testing followed by a one-time decrease in the level of accident fatalities, or was the decrease gradual? To answer these questions, I include lags and leads of the drug-testing variable in the basic regressions estimated in Tables 3 and 4 . I add mutually exclusive indicator variables for 2 years before and 1 year before either adoption of a state law or, if that state did not pass testing legislation prior to 1990 , implementation of the federal mandate. I also include similar indicators for the year of, 1 year after, and 2 or more years after adoption of the law or 
mandate. ${ }^{35}$ This analysis supplements the previous analysis using linear state time trends by allowing for the possibility of nonlinear state trends and considering dynamics in both the premandate and full periods.

Table 7 reveals that over the full period, statistically significant reductions in truck accident fatalities occurred in the year after drug testing officially began. However, the decreases may have started prior to the implementation deadline. These dynamics are not surprising given the almost 2-year lag between the 1988 announcement of DOT testing regulations and the 1990 implementation deadline. Some trucking companies may have started testing before the required date, and some drivers with drug problems may have opted to find other jobs in anticipation of future testing requirements. The bulk of the reductions in truck accident fatalities, however, followed the implementation of testing. In contrast, as suggested when using linear state trends in the basic analysis, the "effect" of testing regulations on car accident fatalities over the whole period seems to be driven by preexisting trends. Indeed, the differences in the timing of decreases in fatalities across all, car, and truck accidents further support the view that testing caused the estimated decreases in truck accident fatalities. The bulk of declines in the former two types of fatalities occurred in year 2 and after and thus may reflect the broader testing agenda that followed the DOT mandate.

Large decreases in truck accident fatalities, although not statistically significant, also occurred in the year after adoption of state testing laws in the premandate period. Nonetheless the negative, although again insignificant, coefficients on both the 1- and 2-year lags in the premandate period suggest that the state legislation results may be partially overstated because of (nonlinear) preexisting state trends. This suggestion is particularly relevant given that there are no obvious trends in all or car accident fatalities in the premandate period. As a result, the estimates from the premandate period should be read with some caution. Finding an effect of states with drug-testing laws may be observationally equivalent to a variety of other hypotheses; for example, those states that value highway safety the most may also be the ones that have the least resistance to drug-testing policies. However, the dynamics over the full period, the robustness of the results to state-specific linear time trends, and the evidence, based on the "reverse experiment," of an effect of the federal mandate alone lend credence to the view that mandated drug testing helped reduce truck accident fatalities.

A rough cost-benefit analysis of mandated testing in the industry suggests that the program may have been worthwhile. According to DOT regulations, half of the approximately 6.3 million commercial truckers are subject to random testing each year, and an additional 1.5 percent of those screened

\footnotetext{
${ }^{35}$ Although I use the term "implementation" both here and in Table 6, this makes sense only for the federal mandate. For states with testing legislation, I can determine only the year of adoption.
} 
will test positive and be subject to confirmatory screens. ${ }^{36}$ The direct and indirect costs of an initial drug test in the 1990s are about \$29 and \$35, respectively, and the direct costs of a confirmatory screen are about $\$ 35 .{ }^{37}$ Roughly 20 percent of those who test positive on a confirmatory test will ask for an additional test. The second sample, which must be sent to an outside laboratory and subject to more sensitive tests, costs about $\$ 75$. With an average cost per drug test of $\$ 65$ per trucker $(\$ 64+(.015 \times \$ 35)+$ $(.20 \times .015 \times \$ 75))$ and approximately 3.15 million tests given each year, the total cost of the random testing per year is \$205 million. Reasonable cause, postaccident, follow-up, and preemployment testing add $\$ 52$ million, with the latter tests accounting for over 75 percent of the cost, for a total cost of $\$ 257$ million for the program per year. The estimated 9 percent reduction in fatalities on account of the DOT testing mandate corresponds to 527 lives saved per year. With standard value-of-life estimates of between $\$ 1$ and \$5 million, the benefits of mandated testing for the country as a whole are between $\$ 527$ million and $\$ 2.6$ billion per year. ${ }^{38}$

These cost estimates, however, ignore the disutility to drivers who would have used drugs or who select out of trucking but would have remained absent the policy. They also ignore the possibility that those who leave trucking may find jobs in other occupations with high external costs, although this may have been mitigated by the fact that testing spread to all safetysensitive jobs around the same time. On the flip side, these calculations, which take into account only changes in accident fatalities, understate the true benefits of testing if the policy also caused reductions in the rate or severity of nonfatal accidents. They further understate the true benefits of testing to the extent that drug testing allows firms to screen for behaviors that are correlated with drug use and reduce efficiency without increasing accident fatalities.

One important remaining question is why, if the benefits outweigh the costs, most motor carriers were not testing prior to the mandate. Although truckers do not bear the full costs of their driving, motor carrier companies presumably had proper incentives. Testing offered considerable potential for them to reduce lawsuits from accidents as well as workers' compensation and damaged freight claims. However, as many companies suggested, they were waiting for clarification of the legal implications of workplace testing.

\footnotetext{
${ }^{36}$ The figure of 6.3 million truckers includes both inter- and intrastate drivers and thus may overstate the total costs of testing prior to the implementation of OTETA. Since many intrastate truckers were being tested after the initial testing regulations, including them may make sense.

${ }^{37}$ Charles Rombro at the Federal Motor Carrier Safety Administration, telephone conversation with the author, May 2000; Federal Highway Administration, Final Rule Regulatory Evaluation and Flexibility Analysis: Drug Testing (unpublished report, 1994). Indirect costs include time for sample collection, paperwork, records maintenance, and the 20 minutes per employee per test.

${ }^{38}$ See W. Kip Viscusi, The Value of Risks to Life and Health, 31 J. Econ. Literature 1912 (1993).
} 
The few "early adopters" in the industry were large firms, employing more than 500 drivers, a category that constitutes less than 5 percent of all motor carriers but roughly 15-20 percent of drivers. One such firm, Groot Industries, Inc., an interstate waste collection company that started testing in 1988, stated that their reluctance to test even earlier stemmed from the high informational costs, costs that almost certainly decreased with the passage of the DOT testing regulations.

While Groot Industries contended that their testing program more than "paid for itself," trade associations for small motor carriers were generally against testing regulations. The Owner-Operators Independent Driver's Association, a trade association of 9,000 independent owner-operators, went so far as to file suit to stop DOT drug-testing requirements. ${ }^{39}$ One potential explanation for the sharp divide along the lines of company size is that small firms could not bear the risks of testing in an uncertain legal environment. In short, earlier reluctance to implement drug testing may be attributable to its ambiguous legal status instead of any ex post cost-benefit calculus.

\section{Conclusions}

In the 1980s, the federal government compelled trucking companies to drug test their employees. Some contend that this policy helped to make the highways safer. Others believe that the policy was a needless intrusion and a substantial waste of resources. Both sides of the debate have tended to rely on moral arguments instead of empirical evidence. The work presented here adds some rigor to the debate by exploiting the variation in the likelihood that truckers were tested across states and over time, created by state drugtesting laws and a DOT mandate.

I find that the motor carriage industry reaped clear benefits from testing-a roughly 9-10 percent reduction in accident fatalities. Isolating the effect of the federal mandate alone on states that had previously not passed a testing statute confirms this finding. In addition, informal calculations indicate that the benefits from the decrease in truck-related fatalities may be on the order of two to 10 times the cost of the program. Clarifying the legal boundaries of employee drug testing, however, may have achieved similar benefits at lower cost. Future research is needed, however, to assess the precise mechanism behind the reduction in truck accident fatalities. Did testing have a true effect on the behavior of existing drivers, or did it allow motor carriage companies to select better drivers? More fundamentally, does drug use per se cause accidents, or is it an indication of worker type?

Finally, caution should be used in generalizing these results beyond safetysensitive industries. In the typical job, where one worker's poor performance

\footnotetext{
${ }^{39}$ See Jim Mele, Facing the Tough Questions, Fleet Owner, April 1990, at 75; John D. Schulz, Fuel Tax Rise, Drug Testing Major Truck Issues in 1989, 217 Traffic World 6 (1989).
} 
has few if any negative externalities, the benefits of testing may be small relative to its costs. This begs the question of why many Wall Street firms drug test job applicants. Is testing just an easy way to demonstrate compliance with federal drug-free workplace regulations, or does it allow firms to uncover other undesirable and less easily discerned qualities that are correlated with drug use? Here as well additional research is needed.

\section{DATA APPENDIX}

\section{Construction and Definition of State Panel Data}

Drug-Testing Legislation Indicator. Indicator equals one for all states for 1990-98. Prior to 1990 , the indicator equals one in the year a state adopted drug-testing legislation and all years thereafter. States with laws are, in order of year of passage, Connecticut (1987), Iowa (1987), Louisiana (1987), Minnesota (1987), Montana (1987), Rhode Island (1987), Vermont (1987), Utah (1987), Nebraska (1988), Kansas (1988), Tennessee (1988), Florida (1989), and Maine (1989). Sources: Richard R. Nelson, State Labor Legislation Enacted in 1987, 111 Monthly Lab. Rev. 38 (1988); Richard R. Nelson, State Labor Legislation Enacted in 1988, 112 Monthly Lab. Rev. 40 (1989); Richard R. Nelson, State Labor Legislation Enacted in 1989, 113 Monthly Lab. Rev. 35 (1990).

BAC08 or Percent Blood Alcohol Concentration of .08. Indicator equals one if state has .08 percent blood alcohol limit in given year. States with laws are, in order of year of earliest year effective in this sample, Utah (1983), Oregon (1983), Maine (1988), California (1990), Vermont (1990), Kansas (1990), North Carolina (1993), New Hampshire (1994), New Mexico (1994), Virginia (1994), Alabama (1995), Florida (1995), Georgia (1997), Hawaii (1997), Idaho (1997), and Illinois (1997). Source: National Safety Council, Accident Facts (1995-98).

Mandatory Seat-Belt Laws. Indicator equals one if state has mandatory seat-belt law in effect in given year. This includes states with either a primary law, which means that a motorist can be pulled over and charged for failing to wear his seat belt, or a secondary law, which means that the motorist can be pulled over only for another, more serious offense. Source: National Safety Council, Accident Facts (1995-98).

Fuel Tax or State Motor Fuel Tax Rates. Source: Public Roads Administration, Highway Statistics (1983-98).

State Unemployment Rate. Source: Bureau of Labor Statistics, Local Area Unemployment Statistics (1983-98).

Speed Limit of 65 Miles per Hour. Indicator equals one in year state passed a speed limit of 65 miles per hour and every year thereafter. Source: National Safety Council, Accident Facts (1995-98).

Speed Limit of 70+ Miles per Hour. Indicator equals one in year state passed a speed limit of 70 miles per hour or above and every year thereafter. Source: National Safety Council, Accident Facts (1995-98).

Accident Fatality. Any death involving a motor vehicle. This includes the death of a driver, other motor vehicle occupants, pedestrians, cyclists, and so on. Source: Bureau of Transportation Statistics, Fatal Accident Reporting System (1983-98).

Cars. These (passenger cars) include 2-door, 3-door, and 4-door sedans, hatchbacks, and coupes as well as station wagons and convertibles. This also includes auto pickups and panels but not compact or standard pickups, utility vehicles, minivans, motor homes, or school buses. Note that a "car accident fatality" involves at least 
one car. It may involve no other vehicles or vehicles of other types, whether passenger cars, trucks, utility vehicles, mopeds, and so on. Source: Bureau of Transportation Statistics, Fatal Accident Reporting System (1983-98).

Trucks. "Trucks" as used here are also referred to as "large trucks." They have gross vehicle weights over 26,000 pounds and include single-unit straight trucks as well as truck/tractors with any number of trailing units. They are almost universally commercial motor vehicles. Source: Bureau of Transportation Statistics, Fatal Accident Reporting System (1983-98).

All Registrations. Defined as registrations for all motor vehicles, private and commercial as well as publicly owned. Source: Public Roads Administration, Highway Statistics (1983-98).

Truck Registrations. Defined as registrations for private and commercial trucks. Source: Public Roads Administration, Highway Statistics (1983-98).

Vehicle Miles Traveled or Annual Vehicle Miles Traveled. Except for Delaware and the District of Columbia, this is defined as millions of vehicle miles traveled on rural interstate. For Delaware, the measure is millions of vehicle miles traveled on other rural principal artery, and for the District of Columbia, millions of vehicle miles traveled on urban interstate. Source: Public Roads Administration, Highway Statistics (1983-98).

TABLE A1

Summary Statistics for State Panel Data (State-Year Means)

\begin{tabular}{lcc}
\hline \hline Independent Variable & Premandate, 1983-89 & Full Period, 1983-98 \\
\hline Truck registrations & 786,342 & $1,008,470$ \\
Car registrations & $2,648,683$ & $2,674,229$ \\
All vehicle registrations & $3,622,615$ & $3,775,867$ \\
Total vehicle miles traveled (millions) & 3309 & 3939 \\
Mandatory seat-belt legislation (\%) & 36.1 & 66.1 \\
Speed limit of 65 miles per hour (\%) & 35.6 & 66.4 \\
Speed limit of 70+ miles per hour (\%) & & 8.80 \\
BAC limit of .08 (\%) & 4.40 & 12.9 \\
Unemployment rate & 7.02 & 6.27 \\
Fuel tax (cents) & 13.4 & 16.5 \\
Observations & 357 & 816 \\
\hline
\end{tabular}

NoTE.-BAC: Blood alcohol concentration.

TABLE A2

Robustness Check: Percentage Change in Accident Fatalities and Fatality Rates in Geographically LaRge States, 1983-89 and 1983-98

\begin{tabular}{|c|c|c|c|c|c|c|c|}
\hline \multirow[b]{2}{*}{ INDEPENDENT VARIABLE } & \multirow[b]{2}{*}{ MEAN } & \multicolumn{2}{|c|}{ ALL } & \multicolumn{2}{|c|}{ CARS } & \multicolumn{2}{|c|}{ TRUCKS } \\
\hline & & Levels & Rates & Levels & Rates & Levels & Rates \\
\hline $\begin{array}{l}\text { Premandate period, 1983-89: } \\
\text { Drug-testing legislation }\end{array}$ & .082 & $\begin{array}{r}-4.10 \\
(1.33)\end{array}$ & $\begin{array}{c}-5.67 \\
(1.56)\end{array}$ & $\begin{array}{r}5.10^{+} \\
(1.75)\end{array}$ & $\begin{array}{l}2.30 \\
(.59)\end{array}$ & $\begin{array}{r}-19.7 * \\
(2.42)\end{array}$ & $\begin{array}{r}-18.9^{+} \\
(1.89)\end{array}$ \\
\hline $\begin{array}{l}\text { Mean number of } \\
\text { fatalities or number per } \\
100 \text { million VMT, year by state }\end{array}$ & & 1009 & 23.1 & 881 & 10.5 & 131 & 3.10 \\
\hline
\end{tabular}


TABLE A2 (Continued)

\begin{tabular}{|c|c|c|c|c|c|c|c|}
\hline \multirow[b]{2}{*}{ INDEPENDENT VARIABLE } & \multirow[b]{2}{*}{ Mean } & \multicolumn{2}{|c|}{ ALL } & \multicolumn{2}{|c|}{ CARS } & \multicolumn{2}{|c|}{ TRUCKS } \\
\hline & & Levels & Rates & Levels & Rates & Levels & Rates \\
\hline Full period, 1983-98: & & & & & & & \\
\hline Drug-testing legislation & .598 & $\begin{array}{c}-3.90 \\
(1.34)\end{array}$ & $\begin{array}{r}-2.45 \\
(.88)\end{array}$ & $\begin{array}{l}1.20 \\
(.31)\end{array}$ & $\begin{array}{l}2.37 \\
(.70)\end{array}$ & $\begin{array}{r}-15.5^{* *} \\
(3.42)\end{array}$ & $\begin{array}{r}-14.7 * * \\
(3.37)\end{array}$ \\
\hline $\begin{array}{l}\text { Mean number of } \\
\text { fatalities or number per } \\
100 \text { million VMT, year by state }\end{array}$ & & 958 & 19.3 & 811 & 8.23 & 122 & 2.51 \\
\hline
\end{tabular}

NotE.-Absolute values of $z$-statistics (levels) and $t$-statistics (rates) for coefficients are reported in parentheses. Standard errors are clustered at the state level to correct for serial correlation in accidents. VMT: vehicle miles traveled. Geographically large states are defined as those over 55,000 square miles in area, or greater than the area of the median state. Excluded are Arkansas, Connecticut, Delaware, the District of Columbia, Hawaii, Indiana, Kentucky, Louisiana, Maine, Massachusetts, Maryland, Mississippi, New Hampshire, New Jersey, North Carolina, Ohio, Pennsylvania, Rhode Island, Tennessee, Vermont, Virginia, and West Virginia. Models estimated over the entire period include 448 observations (28 states over 16 years). Models estimated prior to the DOT mandate include 196 observations (28 states over 7 years). "Levels" columns show negative binomial regression models as in Tables 3 and 4 above (see notes to these tables). Effects represent the percentage change in expected fatality counts from passage of a testing law or the federal mandate. "Rates" columns show log-linear models (see notes to Table 5). Effects represent the percentage change in fatality rates. All models include state and year fixed effects and controls for state fuel taxes, seat-belt laws, speed limits, blood alcohol limits and state unemployment rates. The drug-testing indicator equals one in state $s$ in the year it adopted drug-testing legislation and every year thereafter. States with legislation in this sample are, in order of passage, Iowa, Minnesota, Montana, Utah, Nebraska, Kansas, and Florida.

+ Significant at the $10 \%$ level.

* Significant at the $5 \%$ level.

** Significant at the $1 \%$ level.

\section{BIBLIOGRAPHY}

Ackerman, D. L. "A History of Drug Testing." In Drug Testing: Issues and Options, edited by Robert H. Coombs and Louis J. West, pp. 3-21. New York: Oxford University Press, 1991.

Axel, H. "Drug Testing in Private Industry." In Drug Testing: Issues and Options, edited by Robert H. Coombs and Louis J. West, pp. 140-54. New York: Oxford University Press, 1991.

Bertrand, Marianne; Duflo, Esther C.; and Mullainathan, Sendhil. "How Much Should We Trust Differences-in-Differences Estimates?" Working Paper No. 8841. Cambridge, Mass.: National Bureau of Economic Research, March 2002.

Bureau of Labor Statistics. Local Area Unemployment Statistics. Washington, D.C.: U.S. Department of Labor, 1983-98.

Bureau of Labor Statistics. Survey of Employer Anti-drug Programs. Washington, D.C.: U.S. Department of Labor, 1989.

Bureau of Transportation Statistics. Fatal Accident Reporting System. Various years. Data and codebooks available at http://www-fars.nhtsa.dot.gov.

Crandall, Robert W.; Gruenspecht, Howard W.; and Kecker, Theodore. Regulating the Automobile. Washington, D.C.: Brookings Institution Press, 1986. 
Dee, Thomas S. "State Alcohol Policies, Teen Drinking and Traffic Fatalities." Journal of Public Economics 72 (1999): 289-315.

Dee, Thomas S., and Evans, William N. "Teens and Traffic Safety." In Risky Behavior among Youths: An Economic Analysis, edited by Jonathan Gruber, pp. 121-65. Chicago: University of Chicago Press, 2001.

Desmond, Parry. "Drug Screening." Commercial Carrier Journal 145 (1988): $85-90$.

Evans, William N., and Graham, John D. "Traffic Safety and the Business Cycle." Alcohol, Drugs, and Driving 4 (1988): 31-38.

Federal Highway Administration. "Final Rule Regulatory Evaluation and Regulatory Flexibility Analysis: Drug Testing." Unpublished report. Washington, D.C.: Federal Highway Administration, 1994.

Gruber, Jonathan. "The Incidence of Mandated Maternity Benefits." American Economic Review 84 (1994): 622-41.

Hartwell, Tyler D., et al. "Prevalence of Drug Testing in the Workplace." Monthly Labor Review 118 (1996): 35-42.

Hausman, Jerry A.; Hall, Bronwyn H.; and Griliches, Zvi. "Econometric Models for Count Data with an Application to the Patents-R\&D Relationship.” Econometrica 52 (1984): 909-38.

Hayghe, Howard V. "Anti-drug Programs in the Workplace: Are They Here to Stay?" Monthly Labor Review 114 (1991): 26-29.

Hirsch, Barry T. "Trucking Deregulation and Labor Earnings: Is the Union Premium a Compensating Differential?" Journal of Labor Economics 11 (1993): 279-301.

Holcom, M. L.; Lehman, Wayne, E. K.; and Simpson, D. D. "Employee Accidents: Influences of Personal Characteristics, Job Characteristics, and Substance Use in Jobs Differing in Accident Potential." Journal of Safety Research 24 (1993): 205-21.

Hubbard, Thomas N. "The Demand for Monitoring Technologies: The Case of Trucking." Quarterly Journal of Economics 115 (2000): 533-60.

Kaestner, Robert, and Grossman, Michael. "The Effect of Drug Use on Workplace Accidents." Labour Economics 5 (1999): 267-94.

Levitt, Steven D., and Porter, Jack. "How Dangerous Are Drinking Drivers?" Journal of Political Economy 109 (2001): 1198-1237.

Levitt, Steven D., and Porter, Jack. "Sample Selection in the Estimation of Air Bag and Seat Belt Effectiveness." Review of Economics and Statistics 83 (2001): 603-15.

Long, J. Scott. Regression Models for Categorical and Limited Dependent Variables. Advanced Quantitative Techniques in the Social Sciences, Vol. 7. Thousand Oaks, Cal.: Sage Publications, 1997.

McManis, Sam. "Drug Testing Takes a Hit." San Francisco Chronicle, November 5, 1999, p. B1.

Mehay, Steven L., and Liccardo Pacula, Rosalie. "The Effectiveness of Workplace Drug Prevention Policies: Does 'Zero Tolerance' Work?" 
Working Paper No. 7383. Cambridge, Mass.: National Bureau of Economic Research, October 1999.

Mele, Jim. "Facing the Tough Questions." Fleet Owner, April 1990, pp. 75-78.

Mensch, Barbara S., and Kandel, Denise B. "Underreporting of Substance Use in a National Longitudinal Youth Cohort: Individual and Interviewer Effects." Public Opinion Quarterly 52 (1988): 100-124.

National Safety Council. Accident Facts. Itasca, Ill.: National Safety Council, 1995-98.

Nelson, Richard R. "State Labor Laws: Changes during 1987." Monthly Labor Review 111 (1988): 38-61.

Nelson, Richard R. "State Labor Legislation Enacted in 1988." Monthly Labor Review 112 (1989): 40-58.

Nelson, Richard R. "State Labor Legislation Enacted in 1989." Monthly Labor Review 113 (1990): 35-56.

Normand, Jacques; Lempert, Richard O.; and O'Brien, Charles P., editors. Under the Influence? Drugs and the American Work Force. Washington, D.C.: National Academy Press, 1994.

Normand, Jacques; Salyards, Stephen D.; and Mahoney, John J. "An Empirical Evaluation of Preemployment Drug Testing." Journal of Applied Psychology 75 (1990): 629-39.

Olmstead, S. G. "Drug Testing in the Military." In Drug Testing: Protection for Society or a Violation of Civil Rights. Lexington, Ky.: Council of State Governments Press, 1987.

Porter, Richard C. Economics at the Wheel: The Costs of Cars and Drivers. San Diego, Cal.: Academic Press, 1999.

Public Roads Administration. Highway Statistics. Washington, D.C.: U.S. Government Printing Office, 1983-98.

Rose, Nancy L. "Labor Rent Sharing and Regulation: Evidence from the Trucking Industry." Journal of Political Economy 95 (1987): 1146-78.

Rosenfeld, I. "Fatigue, Alcohol and Drugs Identified as Prime Causes of Fatal Truck Accidents." Traffic World 221 (1990): 13-14.

Ruhm, Christopher J. "Alcohol Policies and Highway Vehicle Fatalities." Journal of Health Economics 14 (1996): 435-54.

Ruhm, Christoper J. "Are Recessions Good for Your Health?" Quarterly Journal of Economics 115 (2000): 617-50.

Schulz, John D. "Roadside Government Drug Tests for Truck Drivers Asked by ATA." Traffic World 215 (1988): 17-18.

Schulz, John D. "Fuel Tax Rise, Drug Testing Major Truck Issues in 1989." Traffic World 217 (1989): 6-7.

Standard and Poor's Corporation. "Transportation: Commercial." Standard and Poor's Industry Surveys. New York: Standard and Poor's Corp., February 2000.

U.S. Department of Health and Human Services. Substance Abuse and Mental 
Health Services Administration Office of Applied Studies. Summary of Findings from the 1998 National Household Survey on Drug Abuse. Rockville, Md.: U.S. Department of Health and Human Services, 1999.

Vinzant, D. R. State Highway Safety Legislation. Ann Arbor, Mich.: UMI, 1994.

Viscusi, W. Kip. "The Value of Risks to Life and Health." Journal of Economic Literature 31 (1993): 1912-46.

Walsh, J. Michael, and Gust, Steven W. "Introduction and Summary." Workplace Drug Abuse Policy: Considerations and Experience in the Business Community. Rockville, Md.: U.S. Department of Health and Human Services, Public Health Service, Alcohol, Drug Abuse, and Mental Health Administration, 1989.

Walsh, J. Michael, and Trimble, J. G. "The Politics of Drug Testing." In Drug Testing: Issues and Options, edited by Robert H. Coombs and Louis J. West. New York: Oxford University Press, 1991.

Zwerling, Craig; Ryan, James; and Orav, Endel John. "The Efficacy of Preemployment Drug Screening for Marijuana and Cocaine in Predicting Employment Outcomes." Journal of the American Medical Association 264 (1990): 2639-43. 